\title{
The First Tertiary Fossils of Mammals, Turtles, and Fish from Canada's Yukon
}

\author{
Authors: Eberle, Jaelyn, Hutchison, J. Howard, Kennedy, Kristen, \\ Koenigswald, Wighart Von, MacPhee, Ross D.E., et al.
}

Source: American Museum Novitates, 2019(3943) : 1-28

Published By: American Museum of Natural History

URL: https://doi.org/10.1206/3943.1

BioOne Complete (complete.BioOne.org) is a full-text database of 200 subscribed and open-access titles in the biological, ecological, and environmental sciences published by nonprofit societies, associations, museums, institutions, and presses.

Your use of this PDF, the BioOne Complete website, and all posted and associated content indicates your acceptance of BioOne's Terms of Use, available at www.bioone.org/terms-of-use.

Usage of BioOne Complete content is strictly limited to personal, educational, and non - commercial use. Commercial inquiries or rights and permissions requests should be directed to the individual publisher as copyright holder. 


\title{
AMERICAN MUSEUM NOVITATES
}

Number 3943,28 pp.

October 31, 2019

\section{The first Tertiary fossils of mammals, turtles, and fish from Canada's Yukon}

\author{
JAELYN EBERLE, ${ }^{1}$ J. HOWARD HUTCHISON, ${ }^{2}$ KRISTEN KENNEDY, ${ }^{3}$ \\ WIGHART VON KOENIGSWALD, ${ }^{4}$ ROSS D.E. MACPHEE, ${ }^{5}$ AND GRANT ZAZULA 6
}

\begin{abstract}
Despite over a century of prospecting and field research, fossil vertebrates are exceedingly rare in Paleogene and Neogene rocks in northern Canada's Yukon Territory. Here, we describe the first records of probable Neogene vertebrate fossils from the territory, including tooth fragments of a rhinocerotid, a partial calcaneum of an artiodactyl, shell fragments of the pond turtle Chrysemys s.l. and tortoise Hesperotestudo, and a fragment of a palatine of Esox (pike). Although the tooth fragments cannot be identified solely by traditional paleontological means, we use tooth enamel microstructure, and primarily the presence of vertical Hunter-Schreger bands, to refer them to the Rhinocerotidae. As the only known record of the Rhinocerotidae in North America's western Arctic, the tooth fragments from the Wolf Creek site support the hypothesis that the clade dispersed between Asia and North America across Beringia. The fossils are consistent with a Miocene age for the Wolf Creek site that is inferred from radiometric dates of the Miles Canyon basalt flows in the vicinity of the fossil locality. Further, the tortoise and pond turtle fossils indicate a mild climate in the Yukon at the time, consistent with the vegetation reconstructions of others that indicate a warmer, wetter world in the Miocene than today.
\end{abstract}

\footnotetext{
${ }^{1}$ University of Colorado Museum of Natural History, Boulder, Colorado.

${ }^{2}$ University of California Museum of Paleontology, Berkeley, California.

${ }^{3}$ Yukon Geological Survey, Whitehorse, Yukon, Canada.

${ }^{4}$ Institute of Geosciences (Section Palaeontology) at the Rheinische Friedrich-Wilhelms University, Bonn, Germany.

${ }^{5}$ Department of Mammalogy, American Museum of Natural History, New York.

${ }^{6}$ Yukon Palaeontology Program, Government of Yukon, Whitehorse, Yukon, Canada; and Research and Collections, Canadian Museum of Nature, Ottawa, Ontario, Canada.
} 


\section{INTRODUCTION}

Despite over a century of prospecting and field research, fossil vertebrates have rarely been encountered in Paleogene and Neogene rocks (ca. 66-2.6 Ma; Gradstein et al., 2012) of Canada's Yukon Territory. The lack of fossils is largely reflective of the limited exposure of reliably identified pre-Quaternary (>2.6 Ma) sediments in the heavily vegetated boreal forest that covers much of Yukon, as well as the probable removal of those sediments by repeated glaciation in the southern and eastern parts of the Territory. To date, the Paleogene record comprises just a single fossil bird discovered by paleobotanist J.F. Basinger at a probable Paleocene-aged locality northwest of Dawson City (Skwara and Kurtz, 1988). No fossil vertebrates are documented yet from the Neogene of Yukon. However, from nearby Alaska, a vole is known from the latest Pliocene (Storer, 2003). Marine mammals, including the amphicynodontid ?Kolponomos, a neocete whale, and desmostylians are known from the latest Oligocene or earliest Miocene of the Aleutian Chain, and more derived desmostylians are known from the early middle Miocene of the Alaskan Peninsula and Kodiak Island (Jacobs et al., 2009). The absence of Neogene terrestrial vertebrates in Alaska and Yukon has troubled vertebrate paleontologists because Beringia must have been the terrestrial dispersal route between North America and Asia for many taxa through this period (Sher, 1999). In stark contrast, the Quaternary (ca. 2.6-0.01 Ma) vertebrate record of Yukon is very well represented by over a hundred fossil localities, capturing a diverse vertebrate fauna that includes fishes, an amphibian, over 40 species of birds, and over 80 species of mammals (Harington, 2011).

In this paper we describe the first records, from a poorly documented locality near Whitehorse, of probable Neogene vertebrate fossils from Yukon, including tooth fragments of a rhinocerotid, a partial calcaneum of an artiodactyl, shell fragments of two kinds of turtle, and a fish bone. We provisionally attribute a Miocene age for the fossils, based on their general aspect as well as (more inferentially) ${ }^{40} \mathrm{Ar} /{ }^{39} \mathrm{Ar}$ and $\mathrm{K}$-Ar dates for the Miles Canyon basalt flows in the vicinity of the fossil locality (Hart and Villeneuve, 1999).

Although most Neogene fossil mammals can be identified to lower taxonomic levels by dental morphology, the tooth fragments from Yukon that here we attribute to a rhinocerotid are so incomplete as to be undiagnostic and cannot be identified solely by traditional paleontological means. Therefore, we looked to the analysis of tooth enamel microstructure to assist with their identification. The microstructure of tooth enamel, the hardest and most resistant material produced by a vertebrate, can provide phylogenetic and taxonomic information as well as insights into the biomechanical properties of teeth (Koenigswald, 1997). Enamel microstructure consistently and predictably differs among clades of Perissodactyla (e.g., Rensberger and Koenigswald, 1980; Fortelius, 1984; Koenigswald et al., 2011), Rodentia (e.g., Martin, 1997; Koenigswald, 2004), and other groups, allowing the conclusion that these fragments are indeed attributable to Rhinocerotidae. This nearly extinct family of large-bodied perissodactyls is represented today by five extant species in Africa and southern Asia. Rhinos appeared in North America in the middle Eocene, and were among the most common large herbivores on this continent until their disappearance near the Miocene-Pliocene boundary (Prothero, 2005). 


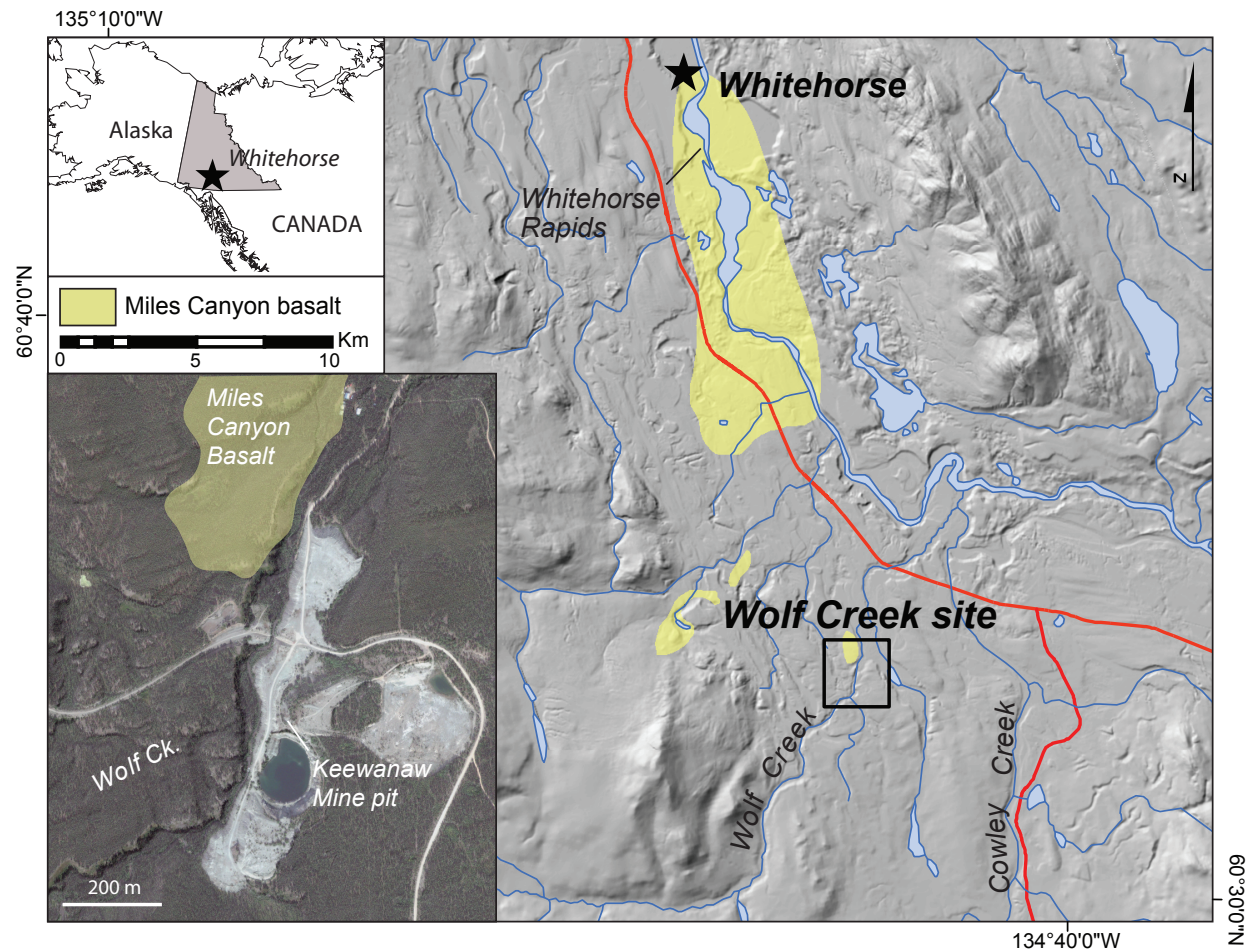

FIGURE 1. Map showing location of Wolf Creek site. Geology from Yukon Geological Survey (2019).

Finally, we discuss the biostratigraphic, biogeographic, and paleoclimatic implications of these Yukon fossils. Although we cannot identify the genus of the rhino based on its enamel microstructure, we are able to provide some paleoenvironmental information by way of the turtle fossils recovered from the same locality.

\section{MATERIALS AND METHODS}

The mammalian tooth, turtle shell and fish bone fragments, and other, currently unidentified, fossil bone fragments were collected by former Whitehorse resident Joan Hodgins (now of Eastend, Saskatchewan) and a group of students on April 28, 1973, apparently from mine tailings in the vicinity of an open-pit copper mine situated near Wolf Creek, southeast of Whitehorse, Yukon (fig. 1). Although the precise locality of the fossils is not known, despite several efforts to relocate it, discussions with Ms. Hodgins, as well as notes and photos she took on their hike that day, suggest that the fossils were collected from a large pile of waste rock stacked along the south side of present-day Wolf Creek. The specimens were presented to paleontologist John Storer while he was working at Eastend, Saskatchewan, who then brought them back to the Yukon when he became the curator of the Yukon Government Palaeontology Program collections in Whitehorse. 


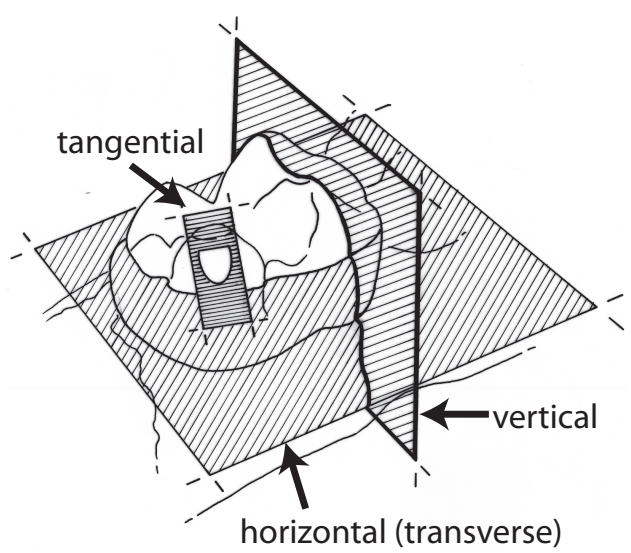

FIGURE 2. Orientation of the three traditional planes of section used to study the enamel microstructure, modified from Koenigswald (1997).

Given their similarity in size, enamel thickness, and overall appearance, and the fact that they were recovered in the vicinity of one another, the mammalian tooth fragments probably represent the same taxon and perhaps the same individual. However, their external morphology does not allow us to reliably identify the mammal to which they belong; therefore, we tried to identify them based on their enamel microstructure. The most complete piece of enamel is YG 514.11. We chose not to section YG 514.11 for enamel microstructure analysis, but rather we kept the specimen intact for morphologic comparisons. It is described below. To investigate the microstructure of the tooth enamel of YG 514.12, three traditional planes of section were studiedhorizontal (or transverse), vertical, and tangential sections (fig. 2; Koenigswald, 1997).

Based upon their thickness and size, the mammalian tooth fragments are from a relatively large mammal. The techniques for preparing and studying tooth enamel microstructure of large fossil mammals were described by Koenigswald and Rose (2005) and are summarized below.

YG 514.12 was carefully studied under a light microscope to determine the direction of the occlusal surface. YG 514.12 was subsequently cut into two pieces, which were embedded in epoxy resin and oriented so that the desired sections (horizontal, vertical, and tangential) were placed parallel to the resin surface. The embedded specimens were placed under a fume hood for 48 hours at room temperature for the epoxy to harden. YG 514.12 was cut using an Isomet $\odot$ low-speed saw with $0.3 \mathrm{~mm}$ blade thickness, to produce horizontal, vertical, and tangential sections. The sections were ground in three steps. First, they were ground down to the enamel surface using a grinding wheel (grit 240). Next, hand-grinding was done on fine, wet sandpaper (grit 800) placed over a glass sheet, and finally the specimens were ground with fine powder grit (grit 1000) mixed with water on a glass plate. Between each step, the sections of YG 514.12 were analyzed under a light microscope to ensure that grinding was not too extensive. The ground surfaces were rinsed with water, cleaned in an ultrasonic cleaner, blown dry, and etched with $10 \%$ hydrochloric acid $(2$ normal $\mathrm{HCl}$ ) for approximately three seconds. Etching with a strong acid for a short time has been shown to produce a stronger profile than etching with a weak acid for a longer time (Koenigswald and Rose, 2005). 
Prior to scanning electron microscope (SEM) analysis, the sections of YG 514.12 were sputter-coated with gold. SEM analysis was conducted on a Camscan MV 2300 instrument housed in the Palaeontology Section of the Institute of Geosciences and a Cambridge Stereoscan 200 SEM in the Institut für Biodiversität der Pflanzen at the Rheinische FriedrichWilhelms University in Bonn, Germany.

Study of mammalian tooth enamel microstructure extends back over half a century to pioneering research by Korvenkontio (1934), Shobusawa (1952), Boyde (1964, 1976), Koenigswald (1980), and others. Koenigswald and Clemens (1992) and Koenigswald et al. (1993) developed a classification of enamel microstructure. In describing the enamel microstructure of YG 514.12, we follow these authors' hierarchical system of classification wherein the units are defined by their size and level of complexity. First, we briefly describe the crystallites, the smallest units of enamel that are comprised of fine needles of hydroxyapatite. Crystallites have a diameter less than $0.5 \mu \mathrm{m}$ and length of more than $100 \mu \mathrm{m}$, making them 200 times longer than thick (Daculsi et al., 1984; Koenigswald and Rose, 2005). They can be seen under high magnification (1500x and higher). We then describe the prisms that are comprised of bundles of crystallites surrounded by a prism sheath, and whose size and shape differ among clades of mammals. Prisms form at the enamel-dentine junction (EDJ) and grow almost to the outer enamel surface (OES) (Rensberger and Koenigswald, 1980). They are typically arranged in groups or bands with the same prism orientation. Their orientation defines the various enamel types (Clemens, 1997; Koenigswald and Sander, 1997; Koenigswald et al., 2011). The prismatic enamels of mammalian teeth often have two or more different enamel types. These range from radial enamel in which the prisms' long axes are parallel to one another and extend radially from near the EDJ toward the OES, to more complex enamel types in which layers or bands of prisms change their orientations from the EDJ to the OES (Koenigswald and Clemens, 1992). Radial enamel is adaptively significant in that it helps retain sharp cutting edges (Koenigswald, 1997). Among the most often described enamel types are Hunter-Schreger bands (HSB), which are light and dark stripes often seen in light microscopy. Mostly they are arranged horizontally, and only a few taxa, including rhinocerotids, have vertical HSB. It was Quenstedt (1852) who figured the vertical bands as typical for the Miocene rhino Aceratherium from Germany (fig. 3). HSB are an optical phenomenon based on the different prism orientation in alternating bands, forming decussations (Clemens, 1997; Koenigswald et al., 2011). HSB are found in the enamel of most large mammals and function biomechanically as a crack-stopping device analogous to plywood (Pfretzschner, 1988; Rensberger and Koenigswald, 1980; Rensberger, 1992, 2004). The level above the enamel type is the "schmelzmuster", the three-dimensional distribution of enamel types within the enamel that has both biomechanical and phylogenetic controls. The number of possible combinations of enamel types or schmelzmusters is very large (Koenigswald and Sander, 1997).

Thick enamel is challenging to study because the magnification at which the prisms are visible may be too high to discern the pattern of structures within the enamel as a whole. Consequently, in addition to SEM analysis, we studied the sections of YG 514.12 at low magnification under a light microscope using the light-guide effect described by Koenigswald and 

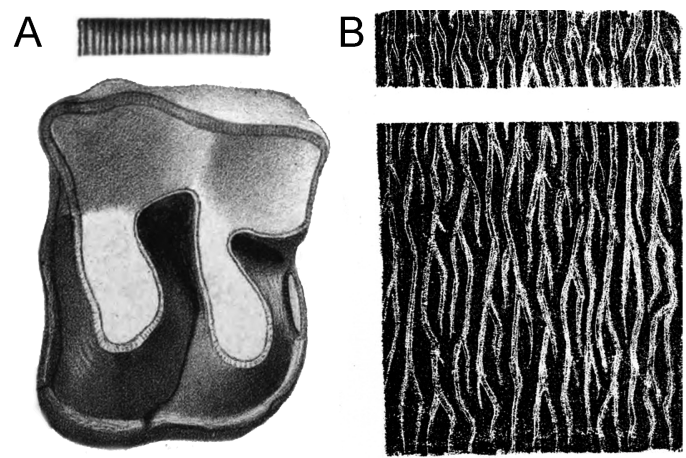

FIGURE 3. Vertical HSB initially observed and figured by Quenstedt (1852: pls. 1, 2) in rhinocerotid molars, from Koenigswald et al. (2011). A. Occlusal view of rhinocerotid upper molar with HSB and cross ridges in the ectoloph. B. Orientation and bifurcation of vertical HSB in the tangential aspect of the rhinocerotid molar.

Pfretzschner (1987) and more recently by Koenigswald and Rose (2005). If light hits an enamel prism approximately perpendicular to its axis, the light is reflected and the prism appears light in color. If, however, the light hits a prism parallel to its long axis, it disappears into the prism, and the prism appears dark. The light and dark bands, each of which is comprised of many prisms with the same orientation, are the HSB. The light-guide effect as a means to discern the presence and orientation of HSB can be used on unprepared tooth enamel as well as sectioned teeth (Koenigswald and Rose, 2005).

Institutional Abbreviations: KOE, Koenigswald enamel collection of the Steinmann Institut, Paleontology, University of Bonn, Germany; UCM, University of Colorado Museum of Natural History; YG, Yukon Government.

Other Abbreviations: EDJ, enamel-dentine junction; HSB, Hunter-Schreger bands; IPM, interprismatic matrix; OES, outer enamel surface; P, prism; SEM, scanning electron microscope.

\section{GEOLOGIC SETTING}

The Wolf Creek site (fig. 1) is underlain by Cretaceous granodiorite of the Whitehorse Batholith, which hosts mineralization previously exploited by the nearby Keewanaw copper mine. Minor plutonic rocks as well as Triassic sandstone and limestone of the Whitehorse Trough assemblage also occur in the area (Hart and Radloff, 1990). Miles Canyon basalt, which includes several dozen isolated occurrences of lava, is generally observed overlying weathered and oxidized granodiorite of the Whitehorse Batholith; however, in some rare cases, basalt overlies variably consolidated gravel and conglomerates (Hart and Villeneuve, 1999; Pearson et al., 2001). ${ }^{40} \mathrm{Ar} /{ }^{39} \mathrm{Ar}$ and $\mathrm{K}$-Ar ages of individual basalt flows range from $\sim 8.9 \mathrm{Ma}$ to 3.2 $\mathrm{Ma}$, and include a K-Ar age of $7.1 \pm 0.4 \mathrm{Ma}$ from a small, steep-sided occurrence adjacent to the mine site at Wolf Creek (Hart and Villeneuve, 1999).

The lack of surface exposure of sediments beneath the Miles Canyon basalt has prevented any detailed or systematic observations of these rocks. Our limited investigations 
of the Wolf Creek basalt occurrence indicate an intensely weathered, poorly sorted, muddy gravel unit below the lowermost basalt flow. Clasts are comprised of local igneous lithologies, and no basalt or glacially modified clasts were observed in these sediments. Based on the K-Ar age of $7.1 \pm 0.4$ for the overlying basalt flow, we interpret the gravel unit to be late Miocene in age.

Given the geological setting, we suggest the most likely source of the collected fossils to be sediments preserved between the Cretaceous granodiorite and overlying Neogene flood basalt. While the fossil-bearing sediments are evidently not exposed at the surface, the existence of gravel of Miocene age at the Wolf Creek site demonstrates the potential to preserve sediments below Miles Canyon basalt.

\section{SYSTEMATIC PALEONTOLOGY}

Class Mammalia

Order Perissodactyla

Family Rhinocerotidae

Rhinocerotidae, gen. et. sp. indet.

Figures 4-9

REFERRED SPECIMENS: YG 514.11, 514.12, and 514.13, cheek tooth fragments comprised of enamel and a small amount of dentine; all specimens from the Wolf Creek mine site, YG fossil locality 105D11-0009.

Description of external morphology: The thickness of the enamel on the YG tooth fragments ranges from approximately 2 to $2.8 \mathrm{~mm}$. The exterior of the enamel is mottled white and tan in color, and it appears to be etched and waterworn; therefore, the thickness of the tooth enamel may have been somewhat greater in life. There are root and/ or invertebrate traces preserved on the enamel exterior. On YG 514.11 (Fig. 4A), morphologically the most diagnostic specimen, the height of the enamel from the base of the cingulum to the occlusal surface is $2.9 \mathrm{~cm}$, indicating a relatively large tooth. YG 514.11 appears to be from the buccal side of a cheek tooth, most probably a lower molar, although possibly from the ectoloph of an upper molar. On the occlusal surface, strong cross ridges are present that extend from the EDJ toward the OES; these can be seen under light microscopy and felt by running a fingernail over the occlusal surface (fig. 4B). Cross ridges are caused by the differential resistance of the underlying enamel prisms to abrasion, dependent upon the prism attitudes. Prisms whose long axes are aligned parallel (or nearly so) to the abrasion vector are more resistant to physical abrasion than those that are perpendicular to the abrasion vector (Rensberger and Koenigswald, 1980; Rensberger, 1995; Rensberger, 2004). Strong cross ridges are characteristic of rhinocerotid cheek teeth, although they can occur in teeth of other large mammals as well. 
A

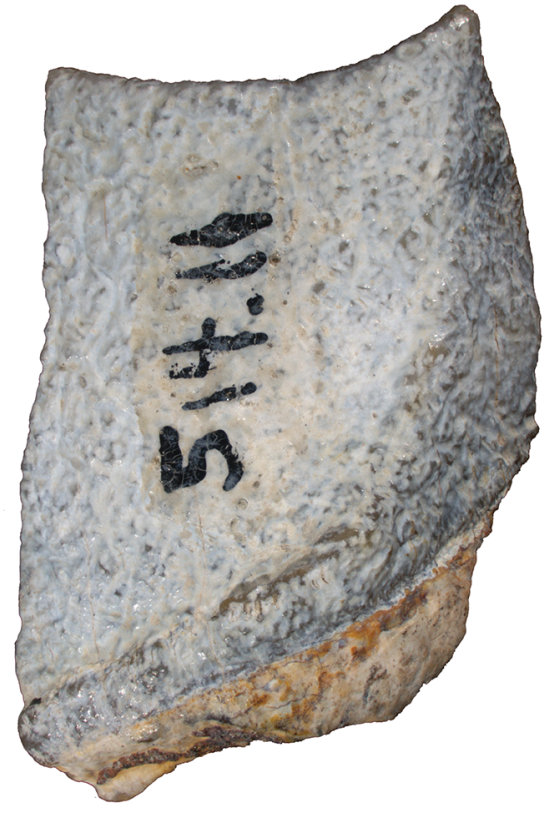

$1 \mathrm{~cm}$

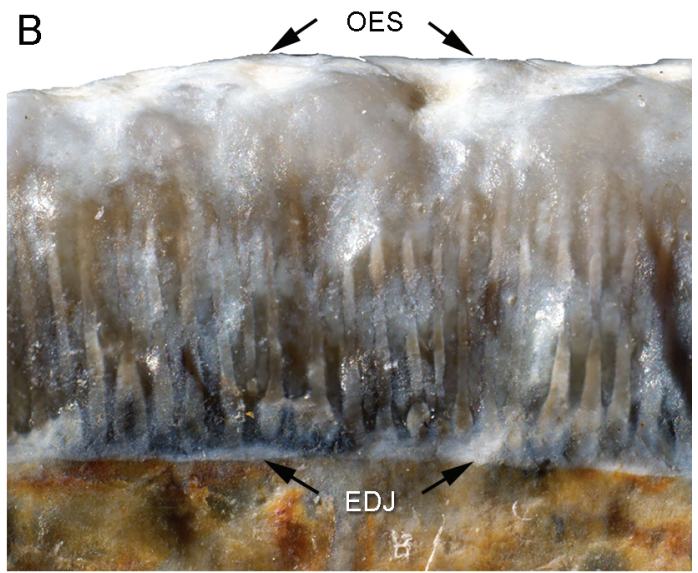

$1 \mathrm{~mm}$

FIGURE 4. YG 514.11, fragment of a probable lower cheek tooth from YG locality 105D11-0009. A. Lateral view. B. Cross ridges on the occlusal surface of the enamel caused by vertical HSB. Abbreviations: EDJ, enamel-dentine junction; OES, outer enamel surface. 


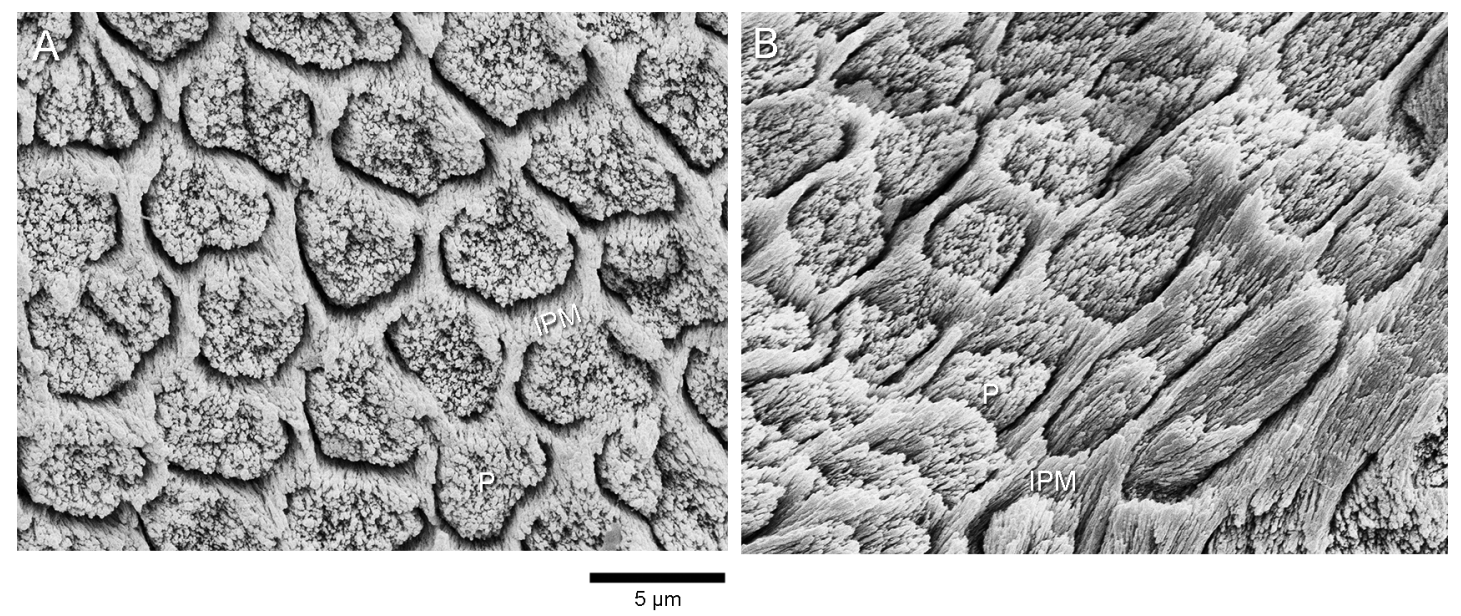

FIGURE 5. SEM images of the crystallites and prisms in the enamel of YG 514.12 (horizontal section). A. Cross section of prisms and surrounding interprismatic matrix; the prism sheath is incomplete. It has been etched away and looks like a trench around each prism. B. Prisms and interprismatic matrix seen in a more oblique angle showing the surrounding IPM. Abbreviations: P, prism; IPM, interprismatic matrix.

\section{Description of the Enamel Microstructure}

\section{Crystallites and Prisms}

Individual crystallites are visible at high magnification in horizontal section (fig. 5), where they appear as fine needles making up the prisms and interprismatic matrix (IPM). The crystallites of the IPM are almost parallel to the prism axis and surround the prisms.

The prisms in YG 514.12 are rounded to irregular in cross section, with some more oblong and narrowing toward the top (fig. 5A). They range in diameter from approximately 4-6 $\mu \mathrm{m}$ and the prism sheaths are open to one side, mostly toward the base of the tooth. The prism sheaths do not appear to touch one another, but rather are surrounded by IPM.

\section{Enamel Types and Schmelzmuster}

The combined interpretation of the horizontal, vertical, and tangential sections of YG 514.12 indicate that the enamel microstructure contains two enamel types-vertical HSB and radial enamel. Our description of the various enamel types involved follows from the EDJ toward the OES because that is the direction of successive mineralization of the enamel. The inner enamel zone is dominated by vertical HSB, which show up as light and dark stripes when viewed under a light microscope using the light-guide effect, as previously noted (fig. 6). Upon examination under SEM, the vertical HSB in the inner enamel zone begin near the EDJ; they are made up of bands with an alternating prism orientation (fig. 7). In one band, prisms rise at about 45 degrees away from the EDJ, and in the adjacent band the prisms descend with about the same angle (fig. 8). The bands of prisms are similar in thickness and spacing from one another (fig. 8A) and are separated by narrow transitional zones of $2-3$ prism widths (fig. 8B). 

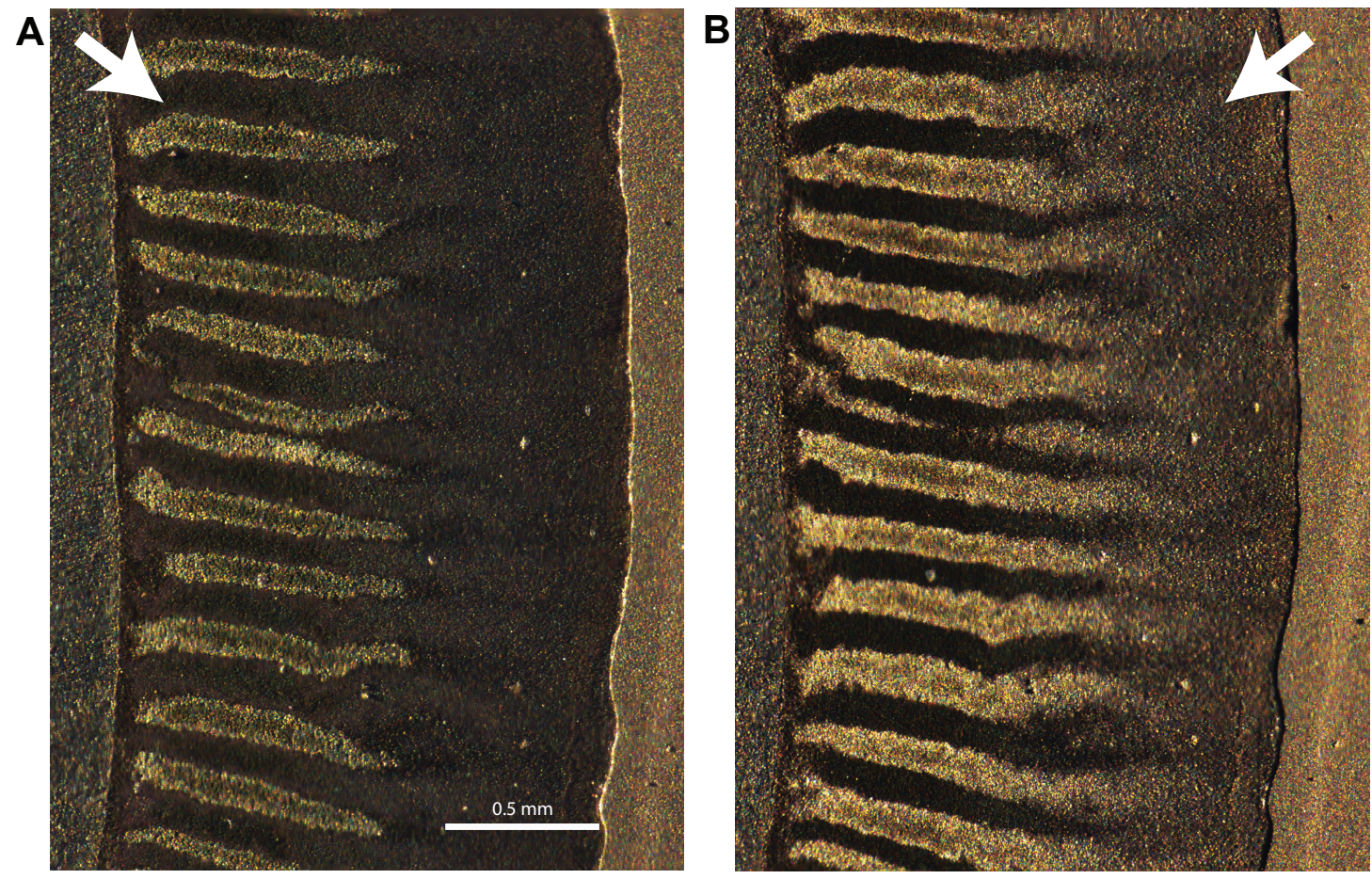

FIGURE 6. Appearance of vertical HSB on the horizontal section of YG 514.12 (etched and sputtercoated) under a light microscope using the light-guide effect. Note that the exact same part of the enamel band is figured. Prisms illuminated perpendicular to their long axis reflect the light and are light colored, whereas prisms illuminated parallel to their long axis are dark in color. A. Light source on left. B. Light source on right.

In the narrow transitional zones, prisms turn sharply from one band to the next and are horizontal for a very short distance (Rensberger and Koenigswald, 1980). The two distinct directions of steeply angled prisms are best seen in the vertical section of YG 514.12 (fig. 8C) - in one set, the prisms descend from the EDJ, whereas in the other, the prisms rise from the EDJ toward the outer enamel surface.

As is evident in the tangential section of YG 514.12 at low magnification using the lightguide effect, the vertical HSB bifurcate in a regular pattern (fig. 9A, B). The light-colored bands bifurcate in only one direction, whereas the dark-colored bands bifurcate in the opposite direction. When the tangential section is illuminated from the opposite side, the optical effect is reversed. That the vertical elements in the enamel complement each other when illuminated from opposing sides indicates that the prism orientation is symmetrical in the alternating vertical bands. The opposing directions of steeply dipping prisms as well as the narrow transitional zones of horizontal prisms are clearly visible in the SEM images of the tangential section (fig. 9C-E).

The outer enamel zone is comprised of radial enamel in which the prisms parallel one another and rise occlusally toward the OES in vertical section (fig. 9F). In order to form the outer radial enamel with a homogeneous prism direction, the prisms of the ascending bands 


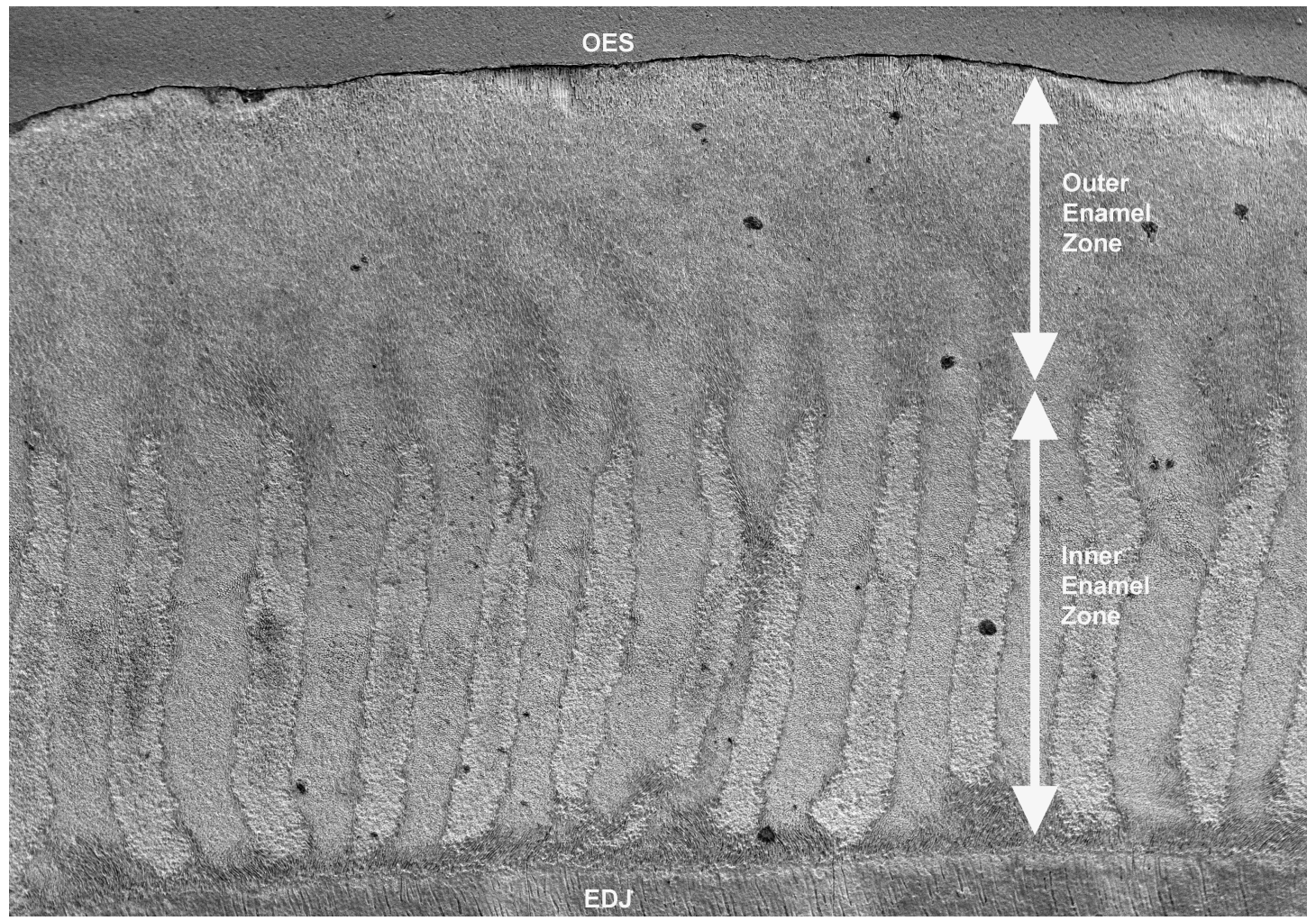

FIGURE 7. SEM image of enamel of YG 514.12 in horizontal section showing the two enamel zones-an inner zone containing vertical HSB and an outer zone of radial enamel.

retain their direction, whereas those with a descending prism direction have to turn upward. Radial enamel is phylogenetically the most primitive enamel type in eutherians and occurs as a thin outer layer in most perissodactyl teeth (Koenigswald, 1997).

\section{Discussion of the Enamel Microstructure of YG 514.12}

Horizontal HSB occur in nearly all large mammals. However, vertical HSB are rare, occurring most notably in the cheek teeth of Rhinocerotidae (Rensberger and Koenigswald, 1980; Rensberger, 2004; Koenigswald et al., 2011). The other taxa known to possess vertical HSB in their cheek teeth are other rhinocerotoids including members of the Hyracodontidae, Amynodontidae, and Peraceratheriidae (= Indricotheriidae), some unrelated South American ungulates (Astrapotherium, Carodnia, and Pyrotherium), and the late Eocene deperetellid tapiroids from Asia (Fortelius, 1985; Rensberger and Pfretzschner, 1992; Rensberger, 2004; Bergqvist and Koenigswald, 2017). Although vertical HSB clearly evolved independently in several lineages, details of structure, especially the modification of the transitional zones between bands, differs in various lineages. For example, a recent study of the enamel of Pyrotherium by Koenigswald et al. (2015) characterizes vertical elements as being wider, with an internal featherlike struc- 

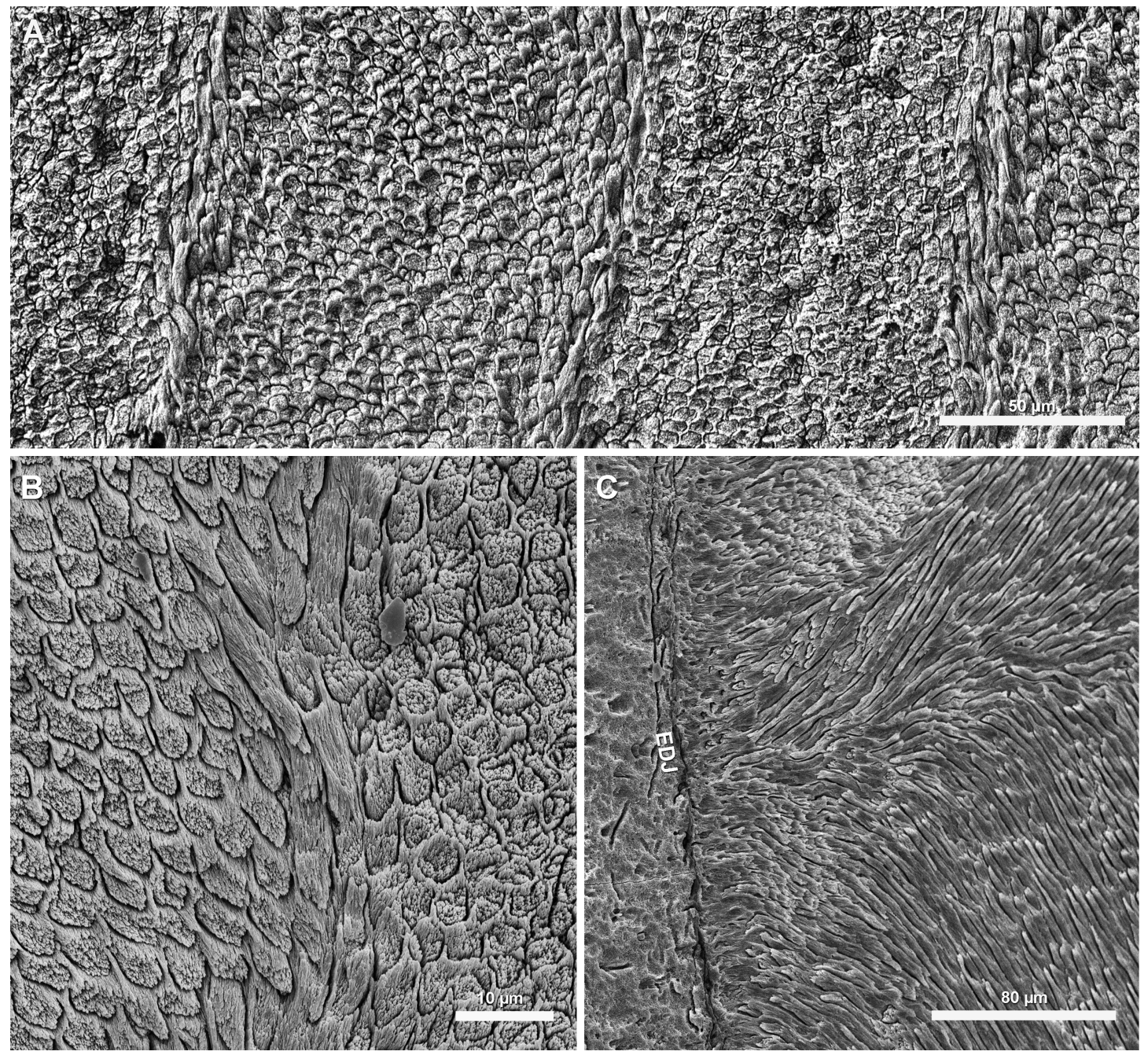

FIGURE 8. A. Magnification of a portion of the horizontal section showing inner enamel zone with uniformly spaced bands of prisms forming the HSB, separated by narrow transitional zones. Prisms of the one band are descending, whereas those of the other band are rising. B. Magnified region of a transitional zone of 2-3 prisms width; prisms on either side of the transitional zone are rising and descending. C. Vertical section showing EDJ and the two opposing directions of steeply angled prisms that comprise the vertical HSB in the inner enamel zone. 

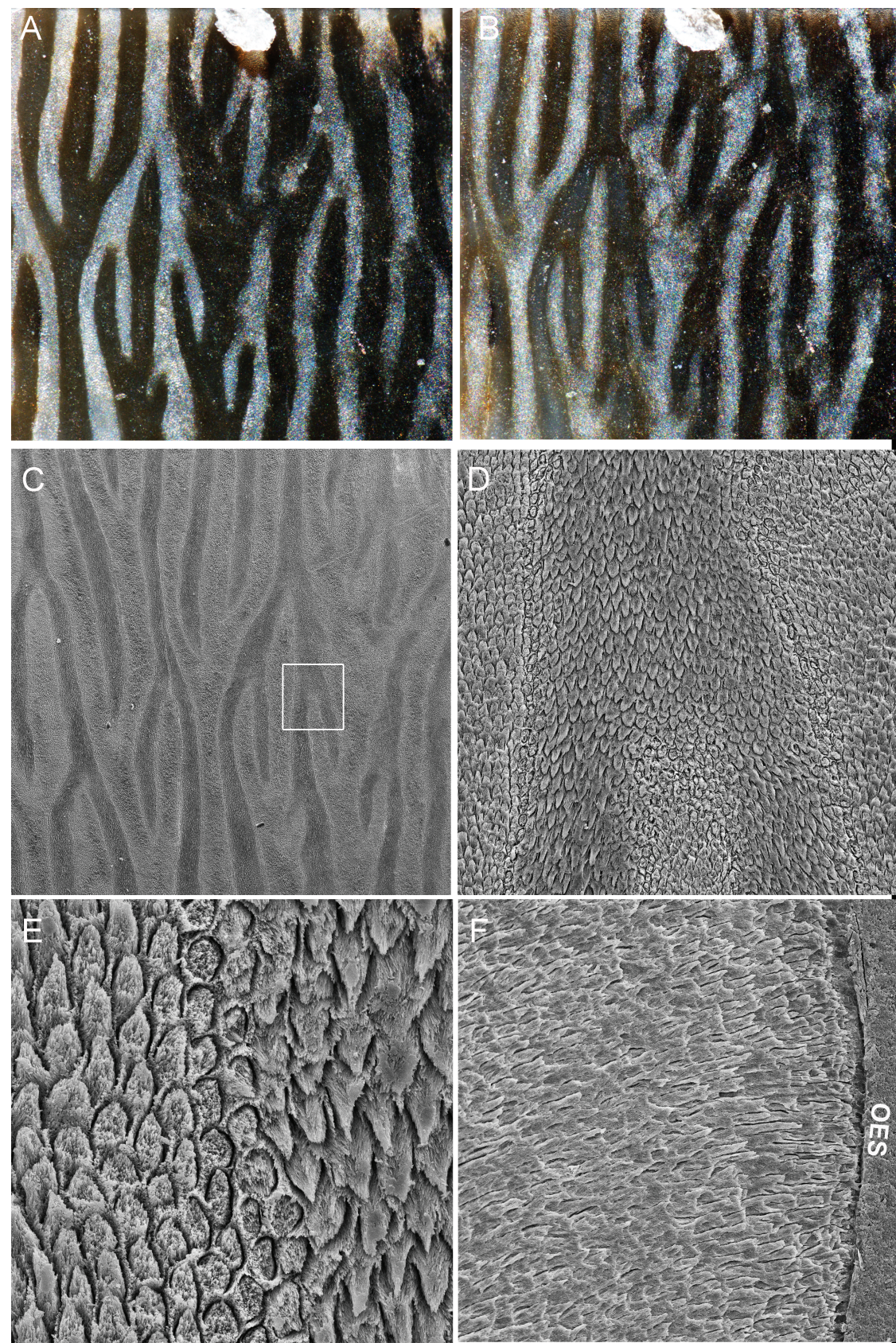

FIGURE 9. A-B. Tangential section of YG514.12 (uncoated) viewed under a light microscope showing the bifurcating vertical HSB. A. Light source from top. B. Light source from bottom. C. SEM image of tangential section. D. Magnified bifurcation in region encompassed by white square in C, showing the steeply angled prisms comprising the HSB; transitional zones are the light-colored edges of the bifurcation. E. Magnified SEM image showing narrow transitional zone of horizontal prisms flanked by the steeply angled prisms that make up the vertical HSB. F. Vertical section of outer enamel showing the radial enamel wherein the prisms rise at a shallow angle toward the OES. Abbreviation: OES, outer enamel surface. 
ture, and thus different from the vertical HSB in rhinocerotoids. In addition, the prisms of Pyrotherium have a keyhole-shaped cross section, again not seen in rhinocerotoids. Finally, whether or not South American native ungulates share a common ancestry with Perissodactyla (Welker et al., 2015), the only documented late Cenozoic member of this group known from North America is the derived notoungulate Mixotoxodon (Lundelius et al., 2013).

More likely, at least by relationship, are members of Brontotheriidae, an extinct family of perissodactyls that inhabited North America, including the Arctic region, during the Eocene (Mihlbachler, 2008; Eberle and Storer, 1999; Eberle, 2006; Eberle and Eberth, 2015). Their teeth are of comparable size, but their HSB are curved, concave upward. Lambdotherium, considered a sister taxon of brontotheres by Mihlbachler (2008), has transverse (or horizontal) HSB. Equids also have transverse HSB, and tapiroids have transverse or curved HSB (Koenigswald et al., 2011). Successively less likely candidates may be summarized as follows. Chalicotheres, an unusual family of large-bodied, clawed perissodactyls that lived in North America during the Eocene and Miocene, but survived into the Pleistocene in Eurasia, have U-shaped HSB in their enamel (Koenigswald, 1994). Artiodactyls are characterized by a transverse orientation of the HSB combined with some radial enamel (Koenigswald, 1997). In some genera, an inner layer of modified radial enamel occurs (Pfretzschner, 1994). Entelodonts show undulating HSB (Stefen, 1995). Proboscideans contrast both artiodactyls and perissodactyls in having irregular or 3-D enamel that contains three-dimensional bundles of prisms that are interwoven and exhibit a range of angles and attitudes with no uniform pattern (Pfretzschner, 1992; Koenigswald, 1997).

In sum, enamel features characteristic of the foregoing taxa fail to display any similarity to the vertical HSB in the tooth fragment YG 514.12. By contrast, the molar enamel of Rhinocerotidae is characterized by the presence of vertical HSB with narrow, well-defined transitional zones, distinct from most other large mammals that inhabited North America during the Paleogene and Neogene.

Among other rhinocerotoids, the Hyracodontidae, Amynodontidae, and Peraceratheriidae (= Indricotheriidae) need to be considered, as their enamel contains vertical HSB (Koenigswald et al., 2011). The Hyracodontidae, considered the most basal group of rhinocerotoids (Wang et al., 2016), are smaller, and have considerably thinner enamel, than the Yukon tooth fragments. For example, the cheekteeth of Hyracodon nebraskensis (UCM 48072), among the largest of the hyracodontids, are approximately half the height and enamel thickness of YG 514.11. Further, the vertical HSB in H. nebraskensis extend to the OES (Koenigswald et al., 2011), unlike YG 514.12 which has an outer enamel zone comprised of radial enamel.

The Amynodontidae are an Eocene-Miocene clade that became extinct in North America during the early Oligocene, but survived into the Miocene in Asia (Wall, 1998). The amynodonts Metamynodon and Cadurcodon have vertical HSB in an inner layer, covered by an outer layer of radial enamel (Koenigswald et al., 2011). The similarity to the schmelzmuster of YG 514.12 raises the question of whether the Yukon tooth fragments belong to an amynodont. However, given that the cheek teeth of the largest North American amynodont Metamynodon planifrons are noticeably taller or higher crowned, yet have thinner enamel, than YG 514.12, it 
seems unlikely. The Peraceratheriidae (= Indricotheriidae), an Asian clade that contains the largest terrestrial mammals that have ever lived on Earth (Radinsky, 1967; Wang et al., 2016), is known to have vertical HSB (specifically in Forstercooperia and Juxia; Koenigswald et al., 2011), although the enamel of many members of this clade has not yet been investigated. North American Uintaceras, considered the sister taxon to the Asian peraceratheres (Wang et al., 2016), has compound enamel in which horizontal (or transverse) HSB occur in an inner zone, and vertical HSB in an outer zone (Koenigswald et al., 2011). Several Asian peraceratheres, including Peraceratherium and Urtinotherium, are too large to be reasonable candidates for the Yukon tooth fragments. Therefore, given the morphology and enamel microstructure of the Yukon tooth fragments, as well as the probable Miocene age for the locality, it seems most parsimonious to conclude that the Yukon tooth fragments belong to a member of the Rhinocerotidae, the only clade of rhinocerotoids to survive into the Neogene.

The Rhinocerotidae first appeared in North America in the middle Eocene (Uintan), with the occurrence of Uintaceras radinskyi (Holbrook and Lucas, 1997). Rhinos were especially diverse and abundant during the Oligocene and Miocene epochs, and disappeared from North America near the Miocene-Pliocene boundary (Hemphillian NALMA; Prothero, 2005). A single fragment of probable rhino tooth from an early Pliocene (Blancan) locality in the Texas Panhandle was hypothesized to represent the last occurrence of the family in North America (Madden and Dalquest, 1990). However, others have since suggested that this fossil was reworked from nearby Hemphillian strata of the Ogallala Formation, and therefore the survival of rhinos into the Blancan is questioned (Prothero, 2005).

The size and thickness of the Yukon tooth fragments indicate a large rhinocerotid, excluding most Eocene members of the family. Beyond this, little more can be said at the moment. YG 514.11 is similar in enamel thickness and height to lower molars of Miocene Aphelops (UCM 43696), and in cingulum development to lower molars of Miocene Diceratherium matutinus (YPM 11873). The molars of the late Eocene rhinocerotid genera Trigonias and Penetrigonias are characterized by vertical HSB, as are all of the investigated Oligocene and Miocene genera from North America (Koenigswald et al., 2011). A more detailed comparison of the enamel in the rhino tooth fragment YG 514.12 with the various Oligocene and Miocene Rhinocerotidae from North America would be desirable, but the necessary datasets of sectioned material do not exist at present. On the other hand, it is very questionable whether the enamel of the Oligocene and Miocene genera diversified to such a degree that significant differences of the vertical HSB would characterize specific genera.

Our reluctance to search for similarities or discrepancies in the schmelzmuster of North American rhinos from the Oligocene and Miocene is strengthened by remarkable similarity of the enamel microstructure of YG 514.12 to the not at all closely related Eurasian Pleistocene woolly rhino Coelodonta antiquitatus (KOE 59; fig. 10), the sister taxon of the extant Sumatran rhinoceros (Yuan et al., 2014). For example, the enamel of C. antiquitatus and YG 514.12 are intriguingly similar in having an inner zone of vertical HSB that are straight and of consistent width and spacing, and an outer zone of radial enamel (Rensberger and Koenigswald, 1980; Koenigswald et al., 2011). Yet this is misleading if taken alone, because the cheek teeth of $C$. 


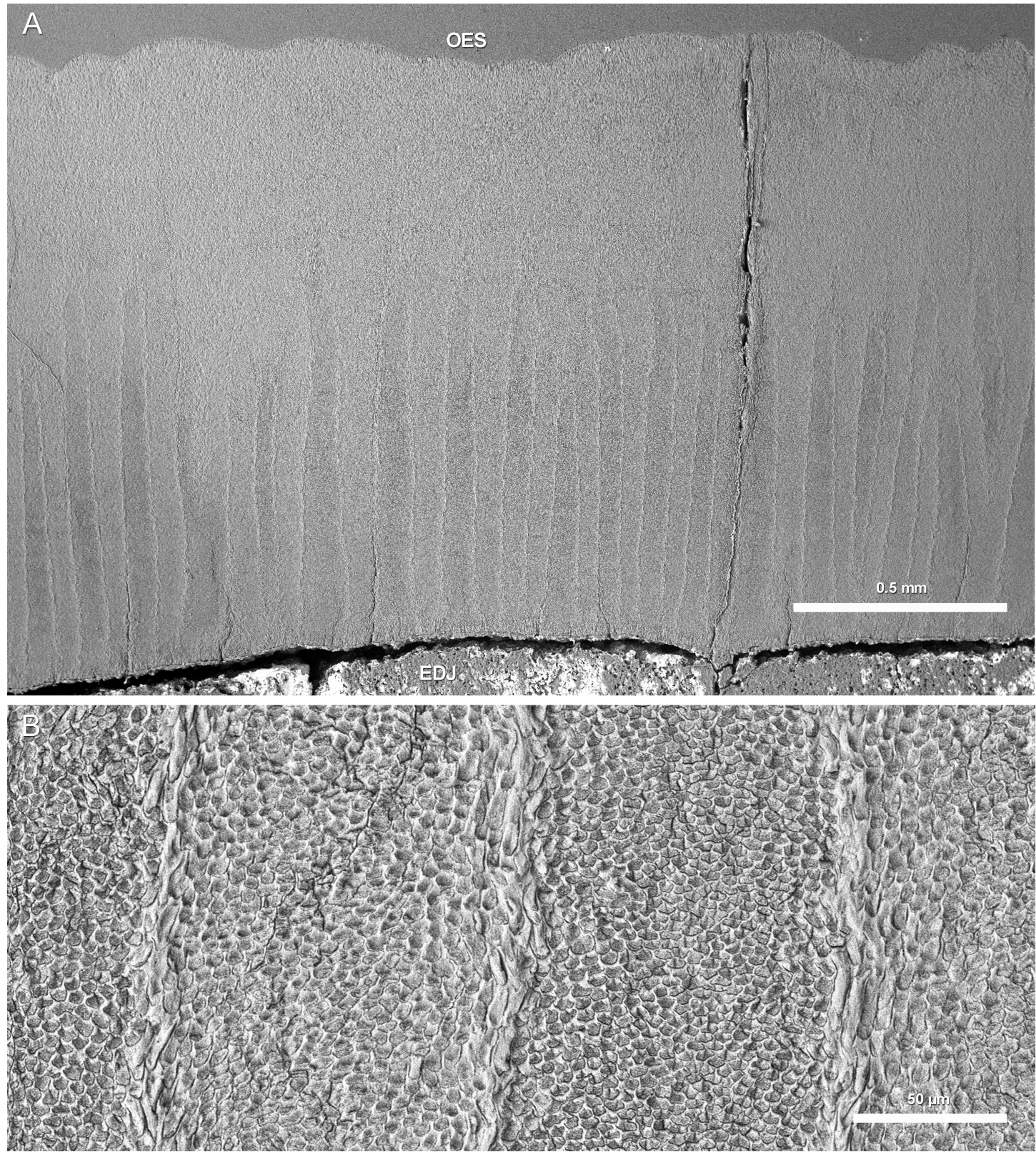

FIGURE 10. SEM images of horizontal section of enamel of Pleistocene rhinocerotid Coelodonta antiquitatis (KOE 59). A. Enamel is comprised of an inner zone of uniformly spaced vertical HSB and an outer zone of radial enamel. B. Magnified image of vertical HSB showing that the bands of prisms are of similar width and spacing and separated by narrow transitional zones, as in YG 514.12. Abbreviations: EDJ, enamel-dentine junction; OES, outer enamel surface. 
antiquitatus are hypsodont with corrugated enamel (Prothero et al., 1986), and are considerably higher crowned than YG 514.11. In short, traditional morphologic evidence clearly indicates that the Yukon fossils cannot be interpreted as belonging to Pleistocene Coelodonta, although what its narrower affinities might be will depend on finding more and better macrofossil evidence.

\title{
Order Artiodactyla
}

Artiodactyla, fam. indet.

Figure 11

RefERred specimen: YG 514.8, fragment of a left calcaneum from YG fossil locality 105D11-0009.

DESCRIPTION: Using the terminology of Hillson (1992), YG 514.8 is an incomplete left calcaneum that is missing its head (i.e., the heel or calcaneal tuberosity) as well as its entire distal end that includes the articular facets. Nevertheless, the shaft is long and relatively narrow when viewed from the dorsal side (fig. 11A), which is comparable to calcanea of artiodactyls (fig. 11C). Additionally, the sustentaculum tali (the process on the medial side for the talus/ astragalus) on YG 514.8 is similar in development and location as on artiodactyl calcanea (fig. $11 C, D)$. In contrast, perissodactyls tend to have a relatively shorter, deeper calcaneal shaft and the sustentaculum tali is much larger (Stains, 1959; Hillson, 1992: fig. 50). YG 514.8 is comparable in size to a number of Cenozoic ungulates, and without the proximal and distal ends, we are unable to identify the specimen beyond Artiodactyla.

\author{
Class Reptilia \\ Order Testudines \\ Family Emydidae \\ Subfamily Deirochelyinae \\ Chrysemys Gray 1844 \\ Chrysemys sp., s.l.
}

Figure 12A

REFERRED SPECIMENS: YG 514.1, left peripheral 8, from YG fossil locality 105D11-0009.

DESCRIPTION: The relatively complete left peripheral 8 is roughly quadratic in outline and the free margin is slightly chipped. The scale-covered surfaces are smooth, in the same plane, and the sulci are well defined. The anterior suture is distinctly thicker $(12.3 \mathrm{~mm})$ than the posterior suture $(8.8 \mathrm{~mm})$. There is no interpleural sulcus and the intermarginal sulcus slopes anterodistally. The marginals extend about two-thirds the width both externally and viscerally. The free margin is acute but chipped and may have been slightly notched at the distal terminus 
A

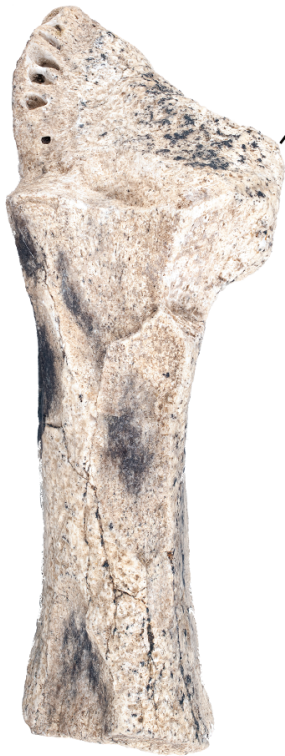

B

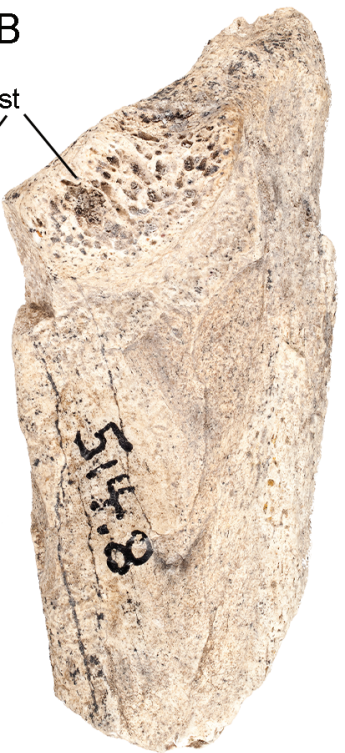

$1 \mathrm{~cm}$
C

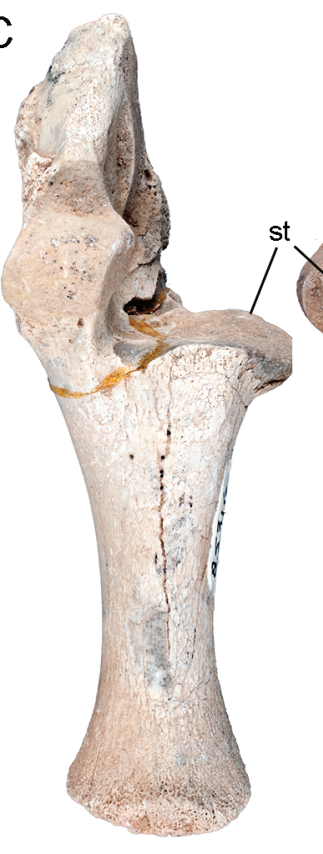

$1 \mathrm{~cm}$

FIGURE 11. Artiodactyla, family indet. A. YG 514.8, fragment of a left calcaneum, dorsal view. B. YG 514.8, medial view. C. UCM 85316, left calcaneum from UCM locality 77023, North Park Formation, Colorado, dorsal view. D. UCM 85316, medial view. Abbreviation: st, sustentaculum tali. 

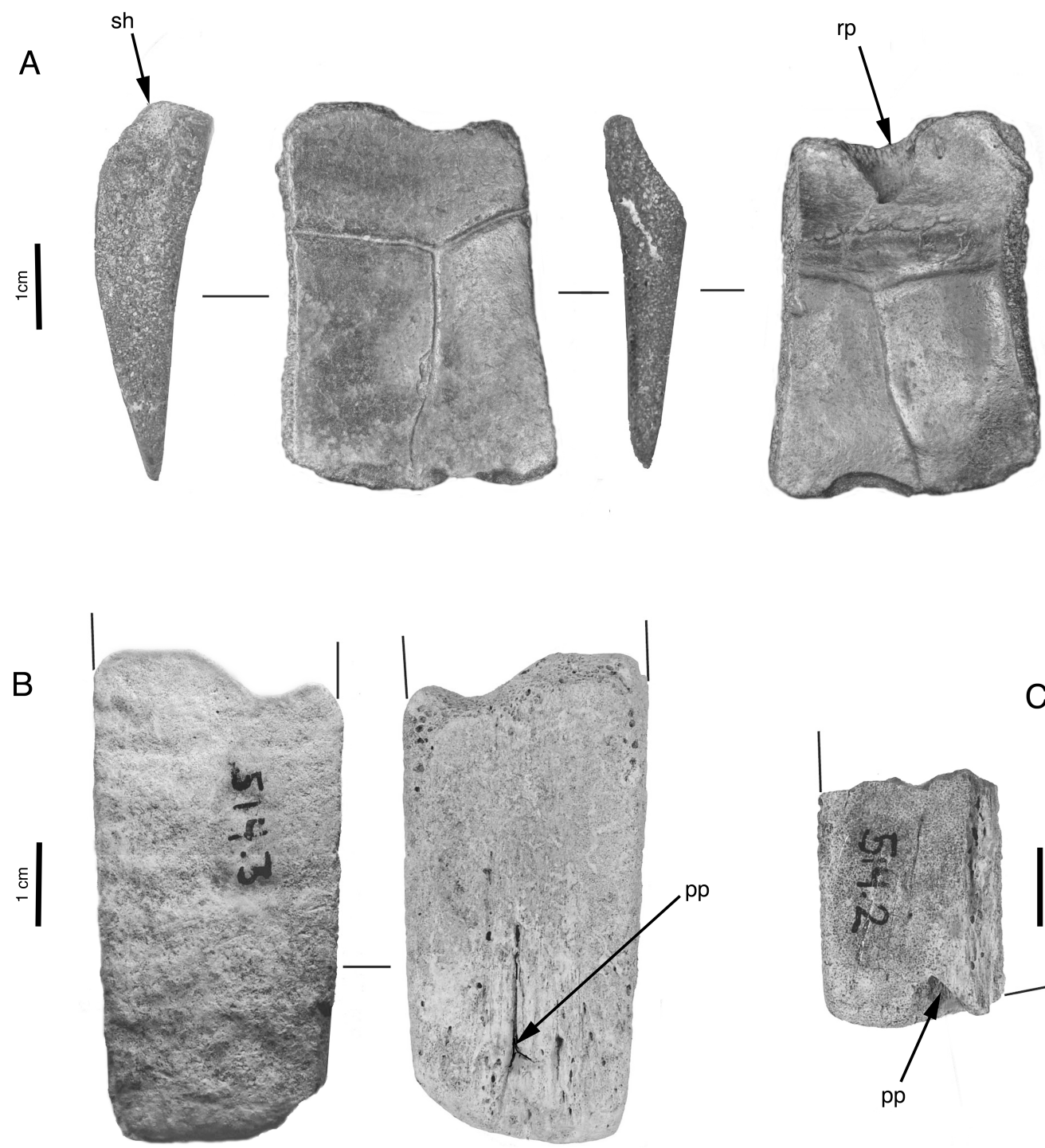

C

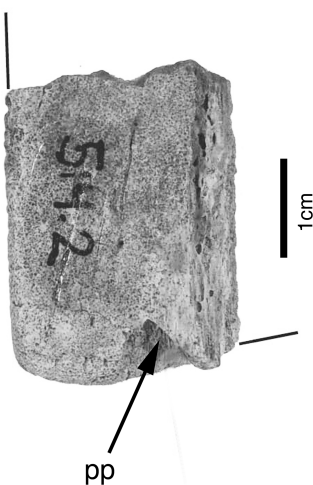

FIGURE 12. Yukon turtles. A. Chrysemys s.l., YG 514.1, left peripheral 8, anterior, external, posterior, and visceral views. B. Hesperotestudo sp. YG 514.3, distal costal 3 or 5, external and visceral views. C. Hesperotestudo sp. YG 514.2, distal costal fragment, external and visceral views. Abbreviations: rp, pit for costal 6 rib; sh, suture for hypoplastron. Scale bars $=1 \mathrm{~cm}$. 
of the intermarginal sulcus. The sutures are all finely dentate with two shallow depressions on the anterodorsal corner for contact with the hypoplastron. The pit for the tip of costal 6 is circular in cross section and penetrates about one-third the width of the peripheral and lies just posterior to the middle of the costal suture. The external surface is very slightly concave laterally. The peripheral suggests an estimated carapace size of $270 \mathrm{~mm}$ or more.

The peripheral exhibits no diagnostic features of the Kinosternidae, Chelydridae, or Testudinidae, but is consistent with the Emydidae. Within the Emydidae, it differs from the Emydinae and resembles the Deirochelyinae in having the hypoplastral buttress reaching peripheral 8 and being larger than most North American emydines. Within the Deirochelyinae, it differs from Malaclemys Gray, 1844, and probably Graptemys Agassiz, 1857, in proportions, sculpturing, and marginal notching. It differs from Deirochelys Agassiz, 1857, in the absence of surface sculpture, being relatively wider, thinner, and lacking an interpleural sulcus. The remaining genera, Chrysemys, Pseudemys Gray, 1856, and Trachemys Agassiz, 1857, are all members of the Chrysemys s.l. complex. Trachemys and Pseudemys tend to have surface sculpturing, but this may be variably absent while Chrysemys s.s. is smooth. The only extant species of Chrysemys, C. picta (Schneider, 1783), reaches a carapace length of only $254 \mathrm{~mm}$ (Ernst and Lovich, 2009) while the other genera reach over $300 \mathrm{~mm}$. Of these, C. picta (painted turtle) is the most northerly occurring member of the group, ranging from southern Canada to northern Mexico. Chrysemys s.l. ranges in age from Oligocene to Recent (Hutchison, 1996; Joyce et al., 2013). However, it is very unlikely the Yukon specimens represent Pleistocene pond turtles because the generally cold and dry glacial climates of the Quaternary in this high-latitude region did not permit the establishment of reptile populations.

\section{Family Testudinidae}

Hesperotestudo Williams 1950

Hesperotestudo sp.

Figure 12B, C

REFERRED SPECIMENS: YG 514.2 and 514.3, distal costal fragments; YG 514.4, 514.5, and 514.6, abraded shell fragments.

Description: Two waterworn distal costal fragments exhibit the cancellous structure, traces of undulating growth ridges, and adentate and rounded suture for the peripheral with pit or deep spiculate suture for a process from the peripheral that are typical of the Testudinidae. There is no interpleural sulcus on YG 514.3 and the anterior and posterior intercostal sutures are preserved with distal length of $26.0 \mathrm{~mm}$ and proximal length of $30.4 \mathrm{~mm}$, indicating a wedged costal, probably costal 3 or 5 as in other North American tortoises. The external surface has a weak series of longitudinal growth ridges. Near the center of the distal part of the visceral surface, there are long thin grooves for articulation with the costal process of the peripheral. YG 514.2 is less complete but has a grooved pit distally for reception of the costal process of the peripheral. Without a complete element, estimating the carapace length is specu- 
lative, but the fragments suggest a carapace length closer to $300 \mathrm{~cm}$ than $600 \mathrm{~cm}$. In addition to YG 514.2 and 514.3, there are three abraded shell fragments (YG 514.4, 514.5, and 514.6) that probably belong to the same tortoise.

Of the known North American Neogene testudinids, the Yukon specimens have a more undulating and coarser surface texture than Stylemys Leidy, 1851, which went extinct in the middle Miocene (Franz, 2014). Xerobates Agassiz, 1857, and Gopherus Rafinesque, 1832, usually have thinner, but comparably sized costals and more extreme costal wedging. The Yukon specimens are consistent with Hesperotestudo, a genus that ranges from Oligocene-Pleistocene in age (Meylan and Sterrer, 2000). However, it is very unlikely these specimens represent Pleistocene tortoises as the generally cold and dry glacial climates of the Quaternary in this highlatitude region did not permit the establishment of reptile populations.

\section{Class Actinopterygii \\ Order Esociformes \\ Family Esocidae}

Esox Linnaeus, 1758

Esox sp.

Figure 13

REFERRED SPECIMEN: YG 514.36, anterior fragment of a right palatine.

DESCRIPTION: YG 514.36, the anterior part of a right palatine, has the typical morphology of that element in Esox (pike). The oral surface is densely covered with shallow circular pits for tooth attachments. The pits increase in size medially as in other Esox.

Esox is widely distributed in the Northern Hemisphere (Berra, 1981). In North America, the genus ranges as far south as Florida and as far north as Alaska and northern mainland Canada (Lee et al., 1980). Esox ranges in age from Paleocene to Recent (Grande, 1999). Diagnoses of the fossil species rest primarily on postcranial features (Grande, 1999). The palatine fragment indicates a fish about the size of the northern pike, Esox lucius Linnaeus, 1758, which has a body length of 500-700 $\mathrm{mm}$ and larger, and the fossil is within the geographic range of this species. Fossils of northern pike are also known from late Quaternary deposits of the Old Crow Basin in northern Yukon Territory (Crossman and Harington, 1970).

\section{DISCUSSION}

Taken in their totality, the fossils of the rhinocerotid, artiodactyl, tortoise, pond turtle, and pike are more consistent with a Miocene age for the Wolf Creek site than for any other epoch. This conclusion is indirectly consistent with radiometric dates on the Miles Canyon basalt flows from the same area in which the fossils were discovered. Although the Rhinocerotidae first appeared in North America in the middle Eocene, the size and thickness of the tooth fragments 


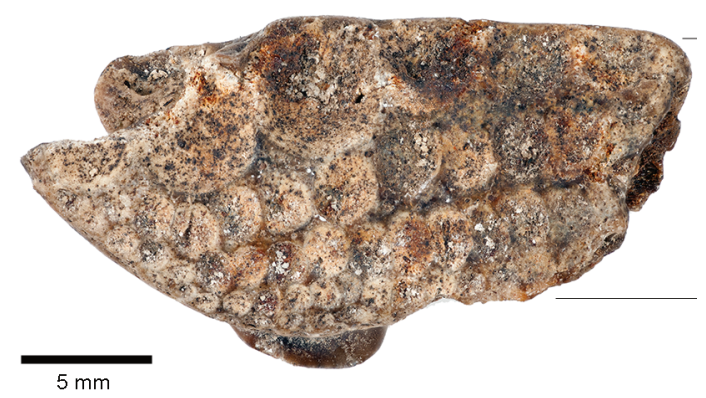

FIGURE 13. Esox sp. YG 514.36, ventral (oral) side of anterior fragment of a right palatine.

from the Wolf Creek site suggest they are from a rhino with a body size larger than projected for Eocene taxa, but similar to that for species that lived during the Oligocene and Miocene epochs. Similarly, the presence of the tortoise Hesperotestudo and pond turtle Chrysemys imply an age no older than Oligocene for the Wolf Creek site.

Rhinocerotidae are hypothesized to have originated in Asia (Prothero, 1998; Beard, 1998; Antoine et al., 2003; Holroyd et al., 2006), dispersing thereafter multiple times between Asia and North America across Beringia (Prothero, 2005). Although all surviving rhinocerotids are tropical to low-latitude temperate in distribution, as recently as the late Pleistocene there were several taxa that lived as far north as was possible to go in Eurasia. In North America, an undescribed rhinocerotid from early Miocene-aged lake deposits that accumulated in the Haughton impact structure $\left(75^{\circ} 23^{\prime} \mathrm{N} 89^{\circ} 40^{\prime} \mathrm{W}\right.$ ) on Devon Island, Arctic Archipelago (Hickey et al., 1988; Dawson, 1990; Prothero, 2005) represents the only other known occurrence of a member of this family in northernmost North America.

The Yukon rhino fossils are important for another reason. Although Beringia is the hypothesized dispersal route between Eurasia and North America for many mammal groups, Paleogene and Neogene fossils from the far northwestern portion of the continent are remarkably lacking. This is in stark contrast to detailed records from Beringia for intercontinental dispersals of iconic Pleistocene mammal taxa such as bison (Froese et al., 2017) and mammoths (Lister and Sher, 2015). This situation for the Neogene is well demonstrated for camelids, with fossils from the late Miocene of Spain (ca. 6.2 Ma) (Pickford et al., 1995) marking the earliest dispersal of Paracamelus eastward across the Bering land bridge. However, the only high-latitude record of Neogene camels in North America is limited to the mid-Pliocene (ca. 3.5 Ma) of Ellesmere Island, in the northeastern extremity of the Canadian Arctic Archipelago (Rybczynski et al., 2013). Although these camelids of North American origin had certainly passed through Beringia by Miocene time, they did not leave any known fossil record in this vast region. The situation is similar for several other taxonomic groups that must have dispersed to or from North America through Neogene Beringia, but seemingly failed to leave a fossil record in Beringia, such as mastodons (Mammutidae), castoroidin beavers, and ursine bears. As slim as it is, the Wolf Creek rhinocerotid record nevertheless establishes empirically that this group was present in Beringia. 
The fossils of both a tortoise and pond turtle at the Wolf Creek site likewise represent the most northerly occurrences of these families in the Neogene of North America and indicate a mild climate in Yukon at the time. This is consistent with vegetation reconstructions for the late Miocene (Tortonian Age; ca. 11.6-7.25 Ma) that indicate a warmer, wetter world than today, wherein the polar and boreal regions $\left(>60^{\circ} \mathrm{N}\right)$ were dominated by cold evergreen coniferous forests and temperate grasslands (Pound et al., 2011). Despite the rarity of late Miocene paleobotanical data from Canada, in Alaska near Cook Inlet, cool mixed forest extended to $61^{\circ}$ $\mathrm{N}$ and a mixture of cool needleleaf and cold evergreen needleleaf forest grew further north, with estimates of mean annual temperature (MAT) ranging from $4^{\circ}-10^{\circ} \mathrm{C}$ warmer than today (Pound et al., 2011, and references therein). Palynologically based paleoclimate interpretations for Alaska, Yukon, and the western Northwest Territories suggest the region was even milder during the early and middle Miocene, with mean annual temperatures (MAT) ranging from $9^{\circ}$ to $11.5^{\circ} \mathrm{C}$ ca. $15 \mathrm{Ma}$. After $7 \mathrm{Ma}$, a colder drier climate prevailed, indicated by the increased importance of herbs and shrubs in the palynological assemblages (White et al., 1997).

\section{CONCLUSION}

The new fossils from Yukon described in this paper are among the very few Neogene terrestrial vertebrates to have been found to date in high-latitude North America. The remoteness of this part of the continent and the lack of exposure of pre-Quaternary sediments has greatly hindered the development of a robust record of the course and consequences of late Neogene intercontinental dispersals between Asia and North America. This interchange, although smaller and more protracted than the one that would shortly link North and South America from the late Pliocene onward, nevertheless had its own impact on the North American mammalian fauna, as did the subsequent and much better known faunal migrations across the Pleistocene Beringian land bridge. Much remains to be learned about the paleobiogeographical history of this part of the continent, and the fossils described here provide a tantalizing and, we hope, provocative glimpse of what is yet to be found.

\section{ACKNOWLEDGMENTS}

We sincerely thank Joan Hodgins, who discovered the fossils with her students in 1973, bringing them to the attention of paleontologist John Storer while working with him in Eastend, Saskatchewan; Storer later became the Yukon Government Palaeontologist in Whitehorse. Hodgins' notes and photos also allowed G.Z., R.D.E.M., and K.K .to identify the general location of the Wolf Creek site. We also thank John Storer for his interest and encouragement and Elizabeth Hall for taking good care of these fossils for many years before they were systematically examined as part of this study. Enamel microstructure analysis of the rhinocerotid tooth fragments was carried out in the Paleontology section of the Institute of Geosciences at the University of Bonn in Germany, supported by an award to J.E. from the Deutscher Akademischer Austauschdienst/German Academic Exchange Service (DAAD), which enabled her to 
practice the investigation of tooth enamel microstructure together with W.v.K. We sincerely thank Thomas Martin, Chair of Palaeontology at the Institute of Geosciences at the University of Bonn, for providing advice and support during J.E.s research stay at the University of Bonn, and for allowing use of his enamel lab for preparation of YG 514.12 and his imaging lab. We also thank Georg Oleschinski (Palaeontology, University of Bonn) and Hans-Jürgen Ensikat (Institut für Biodiversität der Pflanzen, University of Bonn) who worked with us to produce the SEM images shown in figures 5-10. Nicole Neu-Yagle (University of Colorado) imaged the artiodactyl calcanei for figure 11 in the UCM's Entomology Section. We thank Deane Bowers and Virginia Scott for providing access to the imaging station in the Entomology Section. The comments and suggestions made by reviewers K. Christopher Beard and Pierre-Olivier Antoine, as well as managing editor Mary Knight, considerably improved the manuscript.

\section{REFERENCES}

Antoine, P.-O., et al. 2003. Early rhinocerotids (Mammalia: Perissodactyla) from South Asia and a review of the Holarctic Paleogene rhinocerotid record. Canadian Journal of Earth Sciences 40: 365-374.

Beard, K.C. 1998. East of Eden: Asia as an important center of taxonomic origination in mammalian evolution. In K.C. Beard and M.R. Dawson (editors), Dawn of the age of mammals in Asia. Bulletin of the Carnegie Museum of Natural History 34: 5-39.

Bergqvist, L.P., and W.v. Koenigswald. 2017. The enamel microstructure of Carodnia vieirae (Mammalia, Xenungulata) and some comments to its pattern of its mastication. Palaeontologia Electronica 20.2.30A: 1-15.

Berra, T.M. 1981. An atlas of distribution of the freshwater fish families of the World. Lincoln, NE: University of Nebraska Press, 197 pp.

Boyde, A. 1964. The structure and development of mammalian enamel. Ph.D. dissertation, University of London.

Boyde, A. 1976. Enamel structure and cavity margins. Operative Dentistry 1: 13-28.

Clemens, W.A. 1997. Characterization of enamel microstructure. In W.v. Koenigswald and P.M. Sander (editors), Tooth enamel microstructure: 85-112. Rotterdam: Balkema.

Crossman, E.J., and C.R. Harington. 1970. Pleistocene Pike, Esox Lucius, and Esox sp., from the Yukon Territory and Ontario. Canadian Journal of Earth Sciences 7 (4): 1130-1138.

Dalcusi, G.J., J. Mentaneau, L.M. Kerebel, and D. Mitre. 1984. Length and shape of enamel crystals. Calcified Tissue International 36: 550-555.

Dawson, M.R. 1990. Terrestrial vertebrates from the Tertiary of Canada's Arctic Islands. In C.R. Harington (editor), Canada's missing dimension: science and history in the Canadian Arctic islands, vol. 1: 91-104. Ottawa, Canada, Canadian Museum of Nature.

Eberle, J.J. 2006. Early Eocene Brontotheriidae (Perissodactyla) from the Eureka Sound Group, Ellesmere Island, Canadian high arctic-implications for brontothere origins and high-latitude dispersal. Journal of Vertebrate Paleontology 26: 381-386.

Eberle, J.J., and D.A. Eberth. 2015. Additions to the Eocene Perissodactyla of the Margaret Formation, Eureka Sound Group, Ellesmere Island, arctic Canada. Canadian Journal of Earth Sciences 52: 123-133.

Eberle, J.J., and J.E. Storer. 1999. Northernmost record of brontotheres, Axel Heiberg Island, Canadaimplications for age of the Buchanan Lake Formation and brontothere paleobiology. Journal of Paleontology 73: 979-983. 
Ernst, C.H., and J.E. Lovich. 2009. Turtles of the United States and Canada, 2nd ed. Baltimore: Johns Hopkins University Press.

Fortelius, M. 1984. Vertical decussation of enamel prisms in lophodont ungulates. In R.W. Fearnhead and S. Suga (editors), Tooth Enamel, vol. 4: 427-431. Amsterdam: Elsevier.

Fortelius, M. 1985. Ungulate cheek teeth: developmental, functional, and evolutionary interrelations. Acta Zoologica Fennica 180: 1-76.

Franz, R. 2014. The fossil record for North American tortoises. In D.C. Rostal, E.D. McCoy, and H.R. Mushinsky (editors), Biology and conservation of North American tortoises: 13-24. Baltimore: Johns Hopkins University Press.

Froese, D., et al. 2017. Fossil and genomic evidence constrains the timing of bison arrival in North America. Proceedings of the National Academy of Sciences of the United States of America 114 (13): 3457-3462.

Gradstein, F.M., J.G. Ogg, and F.J. Hilgen. 2012. On the geologic time scale. Newsletters on Stratigraphy 45/2: 171-188.

Grande, L. 1999. The first Esox (Esocidae: Teleostei) from the Eocene Green River Formation, and a brief review of esocid fishes. Journal of Vertebrate Paleontology 19 (2): 271-292.

Harington, C.R. 2011. Pleistocene vertebrates of the Yukon Territory. Quaternary Science Reviews 30: 2341-2354.

Hart, C.J.R., and J.K. Radloff. 1990. Geology of Whitehorse, Alligator Lake, Fenwick Creek Carcross and part of Robinson map areas (105D/11, 6, 3, 2 \& 7). Yukon Geological Survey, Open File 1990-4(G).

Hart, C.J.R., and M. Villeneuve. 1999. Geochronology of Neogene alkaline volcanic rocks (Miles Canyon basalt), southern Yukon Territory, Canada: the relative effectiveness of laser ${ }^{40} \mathrm{Ar} /{ }^{39} \mathrm{Ar}$ and $\mathrm{K}-\mathrm{Ar}$ geochronology. Canadian Journal of Earth Sciences 36: 1495-1507.

Hickey, L.J., K.R. Johnson, and M.R. Dawson. 1988. The stratigraphy, sedimentology, and fossils of the Haughton Formation: a post-impact crater-fill, Devon Island, N.W.T., Canada. Meteoritics 23: 221-231.

Holbrook, L.G., and S.G. Lucas. 1997. A new genus of rhinocerotoid from the Eocene of Utah and the status of North American "Forstercooperia." Journal of Vertebrate Paleontology 17: 384-396.

Holroyd, P.A., et al. 2006. A rhinocerotid perissodactyl from the late middle Eocene Pondaung Formation, Myanmar. Journal of Vertebrate Paleontology 26 (2): 491-494.

Hutchison, J.H. 1996. Testudines. In D.R. Prothero and R.J. Emry (editors), The terrestrial Eocene-Oligocene transition in North America: 337-353. Cambridge: Cambridge University Press.

Jacobs, L.L., A.R. Fiorillo, Y. Nishida, and E.M.G. Fitzgerald. 2009. Mid-Cenozoic marine mammals from Alaska. In L.B. Albright III (editor), Papers on geology, vertebrate paleontology, and biostratigraphy in honor of Michael O. Woodburne: 171-184. Museum of Northern Arizona Bulletin 65, Flagstaff, Arizona.

Joyce, W.G., J.F. Parham, T.R. Lyson, R.C.M. Warnock, and P.C.J. Donoghue. 2013. A divergence dating analysis of turtles using fossil calibrations: an example of best practices. Journal of Paleontology 87: 612-634.

Koenigswald, W.v. 1980. Schmelzstruktur und Morphologie in den Molaren der Arvicolidae (Rodentia). Abhandlungen der Senckenbergischen Naturforschenden Gesellschaft 539: 1-129.

Koenigswald, W.v. 1994. U-shaped orientation of Hunter-Schreger bands in the enamel of Moropus (Chalicotheriidae, Mammalia) in comparison to some other Perissodactyla. Annals of the Carnegie Museum 63: 49-65.

Koenigswald, W.v. 1997. Evolutionary trends in the differentiation of mammalian enamel ultrastructure. In W.v. Koenigswald and P.M. Sander (editors), Tooth Enamel Microstructure: 203-235. Rotterdam: Balkema. 
Koenigswald, W.v. 2004. Enamel microstructure of rodent molars, classification, and parallelisms, with a note on the systematic affiliation of the enigmatic Eocene rodent Protoptychus. Journal of Mammalian Evolution 11 (2): 127-142.

Koenigswald, W.v., and W.A. Clemens. 1992. Levels of complexity in the microstructure of mammalian enamel and their application in studies of systematics. Scanning Microscopy 6/1: 195-218.

Koenigswald, W.v., and H.U. Pfretzschner. 1987. Hunter-Schreger-Bänder im Zahnschmelz von Säugetieren (Mammalia). Anordnung und Prismenverlauf. Zoomorphology 106: 329-338.

Koenigswald, W.v., and K.D. Rose. 2005. The enamel microstructure of the early Eocene pantodont Coryphodon and the nature of zigzag enamel. Journal of Mammalian Evolution 12 (3/4): 419-432.

Koenigswald, W.v., and M.P. Sander. 1997. Glossary of terms used for enamel microstructures. In W.v. Koenigswald and M.P. Sander (editors), Tooth Enamel Microstructure: 267-280. Rotterdam: Balkema.

Koenigswald, W.v., T. Martin, and H.U. Pfretzschner. 1993. Phylogenetic interpretation of enamel structures in mammalian teeth: possibilities and problems. In F.S. Szalay, M.J. Novacek, and M.C. McKenna (editors), Mammal Phylogeny, vol. 2, Placentals: 303-314. New York: Springer.

Koenigswald, W.v., L.T. Holbrook, and K.D. Rose. 2011. Diversity and evolution of Hunter-Schreger band configuration in tooth enamel of perissodactyl mammals. Acta Palaeontologica Polonica 56 (1): $11-32$

Koenigswald, W.v., T. Martin, and G. Billet. 2015. Enamel microstructure and mastication in Pyrotheria (Mammalia). Paläontologische Zeitschrift 89 (3): 593-609.

Korvenkontio, V.A. 1934. Mikroskopische Untersuchungen an Nagerincisiven unter Hinweis auf die Schmelzstruktur der Backenzähne. Annales Zoologici Societatis Zoologicae-Botanica Fennicae. Vanamo 2: 1-274.

Lee, D.S., et al. 1980. Atlas of North American freshwater fishes. North Carolina Biological Survey Publication 1980-12, $867 \mathrm{p}$.

Lister A.M., and A.V. Sher. 2015. Evolution and dispersal of mammoths across the Northern Hemisphere. Science 350: 805-809.

Lundelius, E.L., V.M. Bryant, R. Mandel, K.J. Thies, and A. Thoms. 2013. The first occurrence of a toxodont (Mammalia, Notoungulata) in the United States. Journal of Vertebrate Paleontology 33: 229_ 232.

Madden, C.T., and W.W. Dalquest. 1990. The last Rhinoceros in North America. Journal of Vertebrate Paleontology 10 (2): 266-267.

Martin, T. 1997. Incisor enamel microstructures and systematics in rodents. In W.v. Koenigswald and P.M. Sander (editors), Tooth Enamel Microstructure: 163-175. Rotterdam: Balkema.

Meylan, P.A., and W. Sterrer. 2000. Hesperotestudo (Testudines: Testudinidae) from the Pleistocene of Bermuda, with comments on the phylogenetic position of the genus. Zoological Journal of the Linnean Society 128: 51-76.

Mihlbachler, M.C. 2008. Species taxonomy, phylogeny, and biogeography of the Brontotheriidae (Mammalia: Perissodactyla). Bulletin of the American Museum of Natural History 311: 1-475.

Pearson, F.K., C.J.R. Hart, and M. Power. 2001. Distribution of Miles Canyon basalt in the Whitehorse area and implications for groundwater resources. In D.S. Emond and L.H. Weston (editors), Yukon Exploration and Geology 2000: 235-245. Whitehorse, Canada: Exploration and Geological Services Division, Indian and Northern Affairs Canada.

Pfretzschner, H.U. 1988. Structural reinforcement and crack propagation in enamel. In D.E. Russell, J.-P. Santoro, and D. Sigogneau-Russell (editors), Teeth revisited. Proceedings of the VIIth Inter- 
national Symposium on Dental Morphology. Mémoires du Muséum National d'Histoire Naturelle 53: 133-143.

Pfretzschner, H.U. 1992. Enamel microstructure and hypsodonty in large mammals. In P. Smith and E. Tchernov (editors), Structure, function, and evolution of teeth. London: Freund Publishing House

Pfretzschner, H.U. 1994. Biomechanik der Schmelzmikrostruktur in den Backenzähnen von Großsäugern. Palaeontographica A 234: 1-88.

Pickford, M., J. Morales, and D. Soria. 1995. Fossil camels from the Upper Miocene of Europe: Implications for biogeography and faunal change. Geobios-Lyon 28: 641-650.

Pound, M.J., et al. 2011. A Tortonian (Late Miocene, 11.61-7. $25 \mathrm{Ma}$ ) global vegetation reconstruction. Palaeogeography, Palaeoclimatology, Palaeoecology 300: 29-45.

Prothero, D.R. 1998. Rhinocerotidae. In C.M. Janis, K.M. Scott, and L.L. Jacobs (editors), Evolution of Tertiary mammals of North America, vol. 1: Terrestrial carnivores, ungulates and ungulatelike mammals: 595-605. Cambridge: Cambridge University Press.

Prothero, D.R. 2005. The evolution of North American rhinoceroses. Cambridge: Cambridge University Press, $218 \mathrm{pp}$.

Prothero, D.R., E. Manning, and C.B. Hanson. 1986. The phylogeny of the Rhinocerotoidea (Mammalia, Perissodactyla). Zoological Journal of the Linnean Society 87: 341-366.

Quenstedt, F. 1852. Handbuch der Petrefaktenkunde. Tübingen: Laupp and Siebeck,

Rensberger, J.M. 1992. Relationships of chewing stress and enamel microstructure in rhinocerotoid cheek teeth. In P. Smith and E. Tchernov (editors), Structure, function and evolution of teeth: 163183. London: Freund Publishing House.

Rensberger, J.M. 1995. Relationship of chewing stresses to 3-dimensional geometry of enamel microstructure in rhinocerotoids. In J. Moggi-Cecchi (editor), Aspects of dental biology: palaeontology, anthropology, and evolution: 129-146. Florence: International Institute for the Study of Man.

Rensberger, J.M. 2004. Evidence from the enamel microstructure for reversals in dietary behavior in the transition from primitive Ceratomorpha to Rhinocerotoidea. Bulletin of the Carnegie Museum of Natural History 36: 199-210.

Rensberger, J.M., and W.v. Koenigswald.1980. Functional and phylogenetic interpretation of enamel microstructure in rhinoceroses. Paleobiology 6: 477-495.

Rensberger, J.M., and H.U. Pfretzschner. 1992. Enamel structure in astrapotheres and its functional implications. Scanning Microscopy 6: 495-510.

Rybczynski, N., et al. 2013. Mid-Pliocene warm-period deposits in the High Arctic yield insight into camel evolution. Nature Communications 4: 1-9.

Sher, A. 1999. Traffic lights at the Beringian crossroads. Nature 397: 103-104.

Shobusawa, M. 1952. Vergleichende Untersuchungen über die Form der Schmelzprismen der Säugetiere. Okaijamas Folia Anatomica Japonica 24: 371-392.

Skwara, T., and L. Kurtz. 1988. Searching for fossils in Yukon and Northwest Territories. Musk-ox 36: 29-37.

Stains, H.J. 1959. Use of the calcaneum in studies of taxonomy and food habits. Journal of Mammalogy 40: 392-401.

Stefen, C. 1995. Zahnschmelzdifferenzierungen bei Raubtieren. Carnivora im Vergleich zu Vertretern der Dreodonta, Arctocyonidae, Mesonychidae, Enteleodontidae (Placentalia), Thylacoleodontidae, Dasyuridae, and Thylacinidae (Marsupialia). Ph.D. dissertation, Bonn, Universität Bonn, 190 pp.

Storer, J.E. 2003. The eastern Beringian vole Microtus deceitensis (Rodentia, Muridae, Arvicolinae) in Late Pliocene and Early Pleistocene faunas of Alaska and Yukon. Quaternary Research 60: 84-93. 
Wall, W.P. 1998. Amynodontidae. In C.M. Janis, K.M. Scott, and L.L. Jacobs (editors), Evolution of Tertiary mammals of North America, vol. 1: Terrestrial carnivores, ungulates and ungulatelike mammals: 583-588. Cambridge: Cambridge University Press.

Wang, H., B. Bai, J. Meng, and Y. Wang. 2016. Earliest known unequivocal rhinocerotoid sheds new light on the origin of Giant Rhinos and phylogeny of early rhinocerotoids. Scientific Reports 6: 39607. Online resource (doi: 10.1038.srep39607).

Welker, F., et al. 2015. Ancient proteins resolve the evolutionary history of Darwin's South-American ungulates. Nature 522: 81-84.

White, J.M., et al. 1997. An 18 million year record of vegetation and climate change in northwestern Canada and Alaska: tectonic and global climatic correlates. Palaeogeography, Palaeoclimatology, Palaeoecology 130: 293-306.

Yuan, J., et al. Ancient DNA sequences from Coelodonta antiquitatis in China reveal its divergence and phylogeny. Science China Earth Sciences 57: 388-396.

Yukon Geological Survey, 2019. Yukon digital bedrock geology. Yukon Geological Survey. Online resource (http://www.geology.gov.yk.ca/update_yukon_bedrock_geology_map.html), accessed June $5,2019$.

All issues of Novitates and Bulletin are available on the web (http://digitallibrary. amnh.org/dspace). Order printed copies on the web from:

http://shop.amnh.org/a701/shop-by-category/books/scientific-publications.html or via standard mail from:

American Museum of Natural History-Scientific Publications

Central Park West at 79th Street

New York, NY 10024

(2) This paper meets the requirements of ANSI/NISO Z39.48-1992 (permanence of paper). 